\title{
Risk-reducing Surgery in Women at Risk for Familial Breast or Ovarian Cancer
}

\section{Prophylaktische Operationen bei familiärem Mamma- und Ovarialkarzinomrisiko}

Authors

Affiliations
K. Rhiem ${ }^{1}$, K. Pfeifer ${ }^{2}$, R. K. Schmutzler ${ }^{1}$, M. Kiechle ${ }^{2}$

${ }^{1}$ University Hospital, Center for Familial Breast and Ovarian Cancer, Cologne, Germany

${ }^{2}$ Frauenklinik Rechts der Isar, Technische Universität München, Munich, Germany

Key words
BRCA
gynaecology
genetics
- breast cancer
ovary
- breast
Schlüsselwörter
- BRCA
- Frauenheilkunde
- Genetik
- Mammakarzinom
Ovar
- Mamma

received $\quad 9.8 .2012$

revised 20.8.2012

accepted 20.8.2012

Bibliography

Dol http://dx.doi.org/

$10.1055 / \mathrm{s}-0032-1315362$

Geburtsh Frauenheilk 2012; 72

833-839 @ Georg Thieme

Verlag KG Stuttgart · New York . ISSN 0016-5751

\section{Correspondence}

Dr. Kerstin Rhiem, PD

Center for Familial Breast

and Ovarian Cancer

University Hospital

Kerpener Straße 34

50931 Cologne

kerstin.rhiem@uk-koeln.de

\section{Abstract \\ $\nabla$}

An estimated $5 \%$ of breast cancers and $10 \%$ of ovarian cancers may be due to inherited autosomal dominant breast and ovarian cancer alleles BRCA1 und BRCA2. According to populationbased studies 1 or 2 women per 1000 carry such a risk allele. The cumulative cancer risk for healthy women with a BRCA-mutation is between 60 and $85 \%$ for breast cancer and between 20 and $60 \%$ for ovarian cancer. Recent studies have reported an increased risk for contralateral breast cancer in women after unilateral breast cancer. Since 1997 the German Cancer Aid has supported an interdisciplinary approach for high-risk women consisting of genetic testing, counselling and prevention in 12 specialised centres. Since 2005 this concept has received additional support from health insurance companies, and results have been assessed with regard to outcomes (e.g. reduced mortality due to more intensive early diagnosis). The number of centres has increased to 15 at various university hospitals. These interdisciplinary centres offer women the opportunity to participate in a structured screening programme for the early diagnosis of breast cancer and provide non-directive counselling on the options for risk-reducing surgery, e.g., prophylactic bilateral salpingo-oophorectomy, prophylactic bilateral mastectomy or contralateral prophylactic mastectomy after unilateral breast cancer. Such surgical interventions can significantly reduce the risk of disease, the respective disease-specific mortality and - particularly prophylactic bilateral salpingo-oophorectomy - total mortality in BRCA-mutation carriers.

\section{Zusammenfassung \\ $\nabla$}

Rund 5\% der Brustkrebs- und rund 10\% der Eierstockkrebserkrankungen sind durch eine Mutation in den beiden Hochrisikogenen BRCA1 und BRCA2 bedingt. Nach populationsbasierten Untersuchungen trägt jede 500.-1000. Frau der Allgemeinbevölkerung eine solche erbliche Belastung für Brust- und Eierstockkrebs. Gesunde Frauen, die eine Mutation in einem BRCA-Gen aufweisen, tragen ein lebenslanges Erkrankungsrisiko von 60 bis 85\% für ein Mamma- und von 20 bis $60 \%$ für ein Ovarialkarzinom. Frauen, die bereits an einem Mammakarzinom erkrankt sind, haben auch ein erhöhtes Risiko für die Entstehung eines kontralateralen Mammakarzinoms. Ein Konzept zur Identifikation, genetischen Testung, Beratung und Prävention für diese Hochrisikogruppe wurde im Rahmen eines Verbundprojekts der Deutschen Krebshilfe 1997 in 12 spezialisierten Zentren etabliert. Seit 2005 wird dieses Konzept von den Krankenkassen mittels spezialisierter Verträge unterstützt und bez. harter Endpunkte (z.B. Mortalitätsreduktion durch intensivierte Früherkennung) ausgewertet. Die Zentren wurden zwischenzeitlich auf 15 universitäre Standorte erweitert. In den interdisziplinär ausgerichteten Zentren erhalten die Frauen das Angebot zur Teilnahme an intensivierten Brust-Früherkennungsuntersuchungen sowie zur nicht direktiven Beratung über die Option der prophylaktischen Operationen wie z.B. einer prophylaktischen beidseitigen Salpingo-Oophorektomie, einer prophylaktischen beidseitigen Mastektomie bzw. einer kontralateralen prophylaktischen Mastektomie nach einseitiger Brustkrebserkrankung. Diese Eingriffe reduzieren bei BRCA-Mutationsträgerinnen das Erkrankungsrisiko, die jeweilige krankheitsspezifische Mortalität sowie - bezogen auf die prophylaktische beidseitige Salpingo-Oophorektomie - die Gesamtmortalität erheblich. 


\section{Introduction}

$\nabla$

In Germany around 75000 women develop breast cancer and 8000 women develop ovarian cancer each year [1]. Women with a familial risk of inherited breast and ovarian cancer can be identified in a first step though an analysis of their familial history. A "checklist to identify the familial risk for breast and ovarian cancer" [2] can offer members of a risk family and medical practitioners a first indication whether women are at risk and whether counselling in a specialised centre is indicated (http://www. krebshilfe.de/brustkrebszentren.html). In a second step, molecular genetic analysis is used to ascertain the risk of disease. Interdisciplinary and non-directive counselling must be provided prior to such genetic analysis. The likelihood of a mutation in the BRCA genes depends on the familial constellation, for example the incidence of disease, age at primary diagnosis, and the type of cancer (breast or ovarian cancer) ( $\bullet$ Table $\mathbf{1}$ ). The German Consortium for Hereditary Breast and Ovarian Cancer currently considers a $10 \%$ empirical probability of mutation to be an inclusion criterion for genetic testing [3]. This constitutes one of the inclusion criteria for interdisciplinary counselling and genetic analysis in the specialised centres of the German Consortium (- Table 2) [3].

\section{Genetic Basis for Hereditary Risk of Breast or Ovarian Cancer \\ $\nabla$}

After the discovery of the two high-risk genes BRCA1 und BRCA2 in 1994 and 1995, it took another 15 years until investigations within the German Consortium for Hereditary Breast and Ovarian Cancer succeeded in identifying the third high-risk gene "RAD51C" in 2010 [4]. All three high-risk genes play a key role in the repair of DNA double-strand breaks $[3,4]$. While the known tumour suppressor genes BRCA1 and BRCA2 are present as mutations in around $25 \%$ of families with a history of breast cancer, the newly identified RAD51C gene is only mutated in around $1.5 \%$ of families. The Consortium's specialised centres are currently offering a $R A D 51 C$ gene analysis for persons with a corresponding familial constellation as part of a prospective validation study. Recent studies by the German Consortium and other international study groups have indicated that additional risk genes exist. The incidence of disease and the incidence of mutation for these risk genes in the general population varies widely.

Table 1 Familial constellation and empirical probability of pathogenic mutations in the BRCA genes. Source: German Consortium for Hereditary Breast and Ovarian Cancer, 2011.

\begin{tabular}{ll} 
Constellation & $\begin{array}{l}\text { Empirical proba- } \\
\text { bility of mutation }\end{array}$ \\
& $30.7 \%$ \\
\hline BrCa, of which 2 developed below the age of 51 & $22.4 \%$ \\
\hline 3 BrCa, irrespective of age at diagnosis & $19.3 \%$ \\
\hline 2 BrCa developed below the age of 51 & $9.2 \%$ \\
\hline 2 BrCa, of which 1 developed below the age of 51 & $48.4 \%$ \\
\hline 1 BrCa und 1 OvCa, irrespective of age at diagnosis & $45.0 \%$ \\
\hline 2 or more OvCa, irrespective of age at diagnosis & $10.1 \%$ \\
\hline 1 BrCa developed below the age of 36 & $24.8 \%$ \\
\hline 1 bilateral BrCa, primary diagnosis below the age of 51 & $42.1 \%$ \\
\hline 1 male with BrCa and 1 female with BrCa or OvCa &
\end{tabular}

\section{Einleitung}

$\nabla$

In Deutschland erkranken jährlich etwa 75000 Frauen an einem Mamma- und ca. 8000 Frauen an einem Ovarialkarzinom [1]. Risikofamilien für erblichen Brust- und Eierstockkrebs können in einem 1. Schritt durch eine Stammbaumanalyse identifiziert werden. Eine „Checkliste zur Erfassung einer familiären Belastung für Brust- und Eierstockkrebs“ [2] kann Mitgliedern aus Risikofamilien und betreuenden Ärzten einen ersten Anhalt geben, ob ein Risiko vorliegt und eine Beratung in einem spezialisierten Zentrum indiziert ist (http:// www.krebshilfe.de/brustkrebszentren.html). Molekulargenetische Analysen ermöglichen in einem 2. Schritt eine Konkretisierung des Erkrankungsrisikos. Diesen Untersuchungen muss eine interdisziplinäre und nicht direktive Beratung vorausgehen. Wie wahrscheinlich das Auftreten einer Mutation in den BRCA-Genen ist, hängt von der familiären Konstellation wie beispielsweise von der Erkrankungshäufigkeit, dem Alter bei Erstdiagnose und der Art der Krebserkrankung (Brust- bzw. Eierstockkrebs) ab ( Tab. 1). Innerhalb des Deutschen Konsortiums gilt gegenwärtig eine empirische Mutationsnachweiswahrscheinlichkeit von mindestens $10 \%$ als Einschlusskriterium für eine genetische Testung [3]. Diese ist gegeben, wenn eines der Einschlusskriterien zur multidisziplinären Beratung und Genanalyse in den spezialisierten Zentren des Deutschen Konsortiums erfüllt sind (๑ Tab. 2) [3].

\section{Genetische Grundlagen bei familiärer Brust- und Eierstockkrebsbelastung}

Nach der Entdeckung der beiden Hochrisikogene BRCA1 und BRCA2 in den Jahren 1994 und 1995 dauerte es 15 weitere Jahre, bis es durch Untersuchungen aus dem Deutschen Konsortium Familiärer Brustund Eierstockkrebs heraus 2010 gelang, das 3. Hochrisikogen „RAD51C“ zu identifizieren [4]. Alle 3 Hochrisikogene haben eine Schlüsselfunktion in der Reparatur von DNA-Doppelstrangbrüchen $[3,4]$. Während die bereits lange bekannten Tumorsuppressorgene BRCA1 und BRCA2 bei rund 25\% der familiären Mammakarzinome mutiert vorliegen, ist das neu identifizierte Gen RAD51C nur in ca. 1,5\% der Familien mutiert. In den spezialisierten Zentren des Konsortiums wird bei entsprechenden Familienkonstellationen derzeit eine RAD51C-Genanalyse im Rahmen prospektiver Validierungsstudien angeboten. Aktuelle Untersuchungen des Deutschen Konsortiums wie auch anderer, internationaler Arbeitsgruppen weisen darauf hin,

Table 2 Inclusion criteria of the German Consortium for Hereditary Breast and Ovarian Cancer for multidisciplinary counselling and genetic analysis in specialised centres [3].

Multidisciplinary counselling and genetic testing should be offered in special centres if one of the following is present in one line of a family:

- at least 3 women with breast cancer

- at least 2 women with breast cancer, of which 1 carcinoma developed before the age of 51 years

- at least 2 women with ovarian cancer

- at least 1 woman with breast and ovarian cancer

- at least 1 woman with breast cancer and 1 woman with ovarian cancer

- at least 1 woman with bilateral breast cancer developed before the age of 51

- at least 1 woman with breast cancer developed before the age of 36

- at least 1 man with breast cancer and 1 woman with breast or ovarian cancer 
In families with an increased risk, genetic testing is initially offered to a family member with breast or ovarian cancer (index). If tests offer evidence of an indisputably pathogenic mutation, healthy family members may be offered so-called predictive testing. If predictive analysis excludes the presence of a mutation, this member of the family can be considered as not at particular risk, i.e. the risk of breast and ovarian cancer for this member of the family is not higher than for persons with no familial history. If no cancer-causing BRCA1/2 mutation is identified in the index person, then the genetic test is not informative. In this case, family members are offered the opportunity to participate in an intensified screening programme for breast cancer detection if their residual statistical risk for developing cancer is calculated to be $\geq 30 \%$ or their statistical risk for the presence of a cancercausing BRCA mutation (heterozygote risk) is $\geq 20 \%$ [3].

\section{Characteristics of Hereditary Ovarian Cancer \\ $\nabla$}

The clinical characteristics of epithelial ovarian cancer in BRCA1/ 2-mutation carriers do not differ from those of sporadic ovarian cancer. BRCA1-associated cancers are mainly dedifferentiated from tumours of serous histology and are diagnosed in advanced tumour stages [5-7]. There is less data available for BRCA2-associated ovarian cancer due to the lower prevalence and penetrance of BRCA2-associated ovarian cancer compared to BRCA1associated ovarian cancer. Nevertheless, the existing data indicate that this cancer is similar to BRCA1-associated cancer $[6,8]$. A comprehensive meta-analysis of 26 observational studies of the 5-year survival rates of patients with ovarian cancer showed improved survival rates for BRCA1- (44\%; 95\% CI 40-48\%) and BRCA2-mutation carriers ( $52 \%$; $95 \% \mathrm{CI}, 46-58 \%$ ) compared to patients with no BRCA mutation (36\%; 95\% CI, 34-38\%) [9]. It has been surmised that one of the reasons for the more favourable survival data for mutation carriers is the stronger response of $B R C A$-associated cancers to platinum-based chemotherapy.

\section{Characteristics of Hereditary Breast Cancer \\ $\nabla$}

There are no specific histopathological criteria for BRCA2-associated and non-BRCA1/2-associated breast cancers. In contrast to this, BRCA1-associated breast cancer has characteristic features. It often exhibits the same features as a histological subtype of basal-like breast cancer with a triple-negative phenotype (no expression of oestrogen receptors, progesterone receptors and Her2/neu). These typically dedifferentiated tumours have a characteristic morphology with so-called "pushing margins" and clear lymphocytic infiltration $[5,6,10,11]$. There is a weak correlation between the classic prognosis factors 'tumour size' and 'lymph node status' for these rapidly proliferating tumours with regard to survival [12]. RAD51C-associated breast cancer has a similar clinical course as BRCA2-associated breast cancer [4]. Although there is some evidence that metastasis of triple-negative breast cancer is haematogenous, the data on the 10-year survival rates of persons with BRCA-associated breast cancer are similar to those for sporadic tumours [12]. dass noch weitere Risikogene existieren, die mit sehr unterschiedlichen Erkrankungs- und Mutationshäufigkeiten in der Bevölkerung einhergehen.

Eine Gentestung wird in Familien mit einer erhöhten Belastung zunächst einer an Brust- oder Eierstockkrebs erkrankten Person (Index) angeboten. Sollte bei dieser eine eindeutig pathogene Mutation nachgewiesen werden, ist eine Testung von gesunden Familienmitgliedern im Rahmen einer sog. „prädiktiven Testung“ möglich. Wird eine Mutation im Rahmen einer prädiktiven Analyse dann ausgeschlossen, kann dieses Familienmitglied entlastet werden, d.h. für dieses Familienmitglied liegt das Erkrankungsrisiko für Brust- und Eierstockkrebs nicht über dem von Personen ohne familiäre Belastung. Wird bei der Indexperson keine krankheitsauslösende BRCA1/2-Mutation nachgewiesen, dann ist der Gentest nicht informativ. Familienmitgliedern wird in diesem Fall die Teilnahme an den intensivierten Brustfrüherkennungsuntersuchungen angeboten, wenn für sie ein verbleibendes statistisches Erkrankungsrisiko von $\geq 30 \%$ oder ein statistisches Risiko für das Vorliegen einer krankheitsauslösenden BRCAMutation (Heterozygotenrisiko) von $\geq 20 \%$ berechnet wird [3].

\section{Charakteristika des erblichen Ovarialkarzinoms \\ $\nabla$}

Die klinischen Charakteristika der epithelialen Ovarialkarzinome von

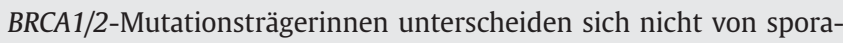
dischen Ovarialkarzinomen. BRCA1-assoziierte Karzinome sind überwiegend vom serösen histologischen Typ, entdifferenziert und werden in einem fortgeschrittenen Tumorstadium diagnostiziert [5-7]. Für BRCA2-assoziierte Ovarialkarzinome sind aufgrund der niedrigeren Prävalenz und Penetranz gegenüber BRCA1-assoziierten Ovarialkarzinomen insgesamt weniger Daten verfügbar. Dennoch weisen die vorhandenen Daten darauf hin, dass diese Karzinome den BRCA1assoziierten ähnlich sind $[6,8]$. Eine umfangreiche Metaanalyse von 26 Beobachtungsstudien zum 5-Jahres-Überleben von Patientinnen mit Ovarialkarzinomen ergab ein verbessertes Überleben für BRCA1(44\%; 95\%-KI 40-48\%) und BRCA2-Mutationsträgerinnen (52\%; 95\%KI, 46-58\%) im Vergleich zu Patientinnen ohne BRCA-Nachweis (36\%; 95\%-KI, 34-38\%) [9]. Als einen Grund für diese günstigeren Überlebensdaten der Mutationsträgerinnen wird das bessere Ansprechen der BRCA-assoziierten Karzinome auf platinhaltige Chemotherapien vermutet.

\section{Charakteristika des erblichen Mammakarzinoms $\nabla$}

Spezifische histopathologische Kriterien des BRCA2- und des nicht$B R C A 1 / 2$-assoziierten Mammakarzinoms existieren nicht. Im Gegensatz dazu weisen BRCA1-assoziierte Mammakarzinome charakteristische Merkmale auf. Sie zeigen häufig den histologischen Subtyp des basalen Mammakarzinoms mit einem triple-negativen Phänotyp (keine Expression von Östrogen-, Progesteronrezeptoren und Her2/ neu). Die typischerweise entdifferenzierten Tumoren weisen eine charakteristische Morphologie mit sogenannten „pushing margins“ und einer deutlichen lymphozytären Infiltration auf [5,6,10,11]. Die rasch proliferierenden Tumoren zeigen eine schwache Korrelation zwischen den klassischen Prognosefaktoren Tumorgröße und Lymphknotenstatus in Bezug auf das Überleben [12]. RAD51C-assozi- 


\section{Ipsi- and Contralateral Breast Cancer Risk}

$\nabla$

A seminal study from within the German Consortium was published on the risk of contralateral breast cancer [13]. A total of 2020 BRCA-mutation carriers with unilateral breast cancer were investigated with regard to their risk for developing secondary disease. The cumulative risk for contralateral breast cancer in this collective was $47.4 \%$ after 25 years. Women with a BRCA1 mutation had a 1.6-fold increased risk of developing contralateral secondary cancer compared to women with a BRCA2 mutation. Younger age at the time of the primary diagnosis was associated with a significantly higher risk for developing contralateral breast cancer in BRCA1-mutation carriers. Only a trend towards increased risk was noted for BRCA2-mutation carriers. Thus, BRCA1-mutation carriers who had developed primary cancer at a young age had the highest risk. In women who developed cancer prior to the age of 40 , the risk of secondary disease after 25 years was $62.9 \%$, compared to only $19.6 \%$ for women who developed primary disease after the age of 50 . This study showed that the risk of secondary disease strongly depended on the affected gene and on the age at primary diagnosis. It is therefore very important to consider these risk factors and communicate them when offering counselling on risk-reducing mastectomy. A further study on the risk of secondary disease in women from families who were negative for BRCA1/2 genes was recently published. This study showed that the risk of disease for women from families without evidence of BRCA mutation is approximately that of women with sporadic breast cancer [14]. Mutation carriers are not at increased risk of ipsilateral recurrence after breast-preserving surgery and adjuvant radiation compared to women with sporadic breast cancer [15].

\section{Breast Cancer Screening}

$\nabla$

The mean age of disease onset in persons with a familial history of breast cancer has been brought forward and is now 45 years of age. The standard measures for screening are not sufficient for the risk collective of mutation carriers or for risk families without detected mutations, as standard mammography screening only starts after the age of 50. By this time, a majority of women with a genetic predisposition has already developed disease. However, if only mammography is used for screening, this will result in a high rate of false-negative findings because of the density of breast tissue in younger women in risk families. The German Consortium has developed a multimodal screening programme, which is now offered throughout all of Germany, with shorter screening intervals and an earlier start of screening $[3,16](\odot \mathrm{Ta}-$ ble 3).

Table 3 Intensive screening programme proposed by the German Consortium for Hereditary Breast and Ovarian Cancer [3].

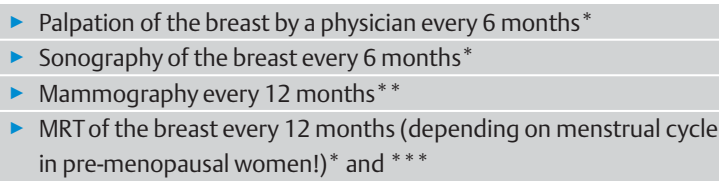

* from the age of 25 or 5 years prior to the earliest age at disease onset in the family

** after the age of 30 ; from the age of 35 if the breast tissue is very dense

*** recommendation for MRT generally only until the age of 55 or until glandular mammary tissue has involuted (ACRI-II) ierte Mammakarzinome zeigen einen ähnlichen klinischen Verlauf wie BRCA2-assoziierte Mammakarzinome [4]. Obwohl es Hinweise auf eine bevorzugt hämatogene Metastasierung insbesondere bei triple-negativen Mammakarzinomen gibt, ähnelt die Datenlage bezüglich des 10-Jahres-Überlebens der BRCA-assoziierten Mammakarzinome denen sporadischer Tumoren [12].

\section{Ipsi- und kontralaterales Mammakarzinomrisiko $\nabla$}

Bei der Frage nach dem kontralateralen Mammakarzinomrisiko ist eine Arbeit aus dem Deutschen Konsortium wegweisend [13]. Es wurden 2020 bereits an einem unilateralen Mammakarzinom erkrankte BRCA-Mutationsträgerinnen bez. ihres Zweiterkrankungsrisikos untersucht. Das kumulative Risiko für ein kontralaterales Mammakarzinom betrug in der Gesamtgruppe nach 25 Jahren 47,4\%. Frauen mit einer BRCA1-Mutation hatten ein 1,6-fach erhöhtes Risiko für ein kontralaterales Zweitkarzinom im Vergleich zu Frauen mit einer BRCA2-Mutation. Ein jüngeres Ersterkrankungsalter ging mit einem signifikant höheren Risiko für ein kontralaterales Mammakarzinom bei BRCA1-Mutationsträgerinnen einher. Bei BRCA2-Mutationsträgerinnen wurde lediglich ein Trend in diese Richtung beobachtet. Das höchste Risiko hatten somit BRCA1-Mutationsträgerinnen, die jung an einem Erstkarzinom erkrankt waren. Bei Frauen, die bereits vor dem 40. Lebensjahr erkrankt waren, betrug das Zweiterkrankungsrisiko nach 25 Jahren 62,9\%, im Vergleich zu nur 19,6\%, die erst nach dem 50. Lebensjahr erkrankt waren. In dieser Arbeit konnte gezeigt werden, dass das Zweiterkrankungsrisiko stark vom betroffenen Gen und vom Alter bei Ersterkrankung abhängt. Daher sollten diese Risikofaktoren bei einer Beratung zu einer prophylaktischen Mastektomie unbedingt beachtet und kommuniziert werden. Eine weitere Untersuchung zu den Zweiterkrankungsrisiken von Frauen aus Familien mit negativem BRCA1/2-Genbefund ist aktuell eingereicht. Diese Arbeit belegt, dass das kontralaterale Erkrankungsrisiko von Frauen aus belasteten Familien ohne BRCA-Mutationsnachweis annähernd dem von Frauen, die an einem sporadischen Mammakarzinom erkrankt sind, ähnelt [14]. Mutationsträgerinnen haben kein deutlich erhöhtes Risiko für ein ipsilaterales Rezidiv nach brusterhaltender Operation und adjuvanter Radiatio im Vergleich zu Frauen mit sporadischem Mammakarzinom [15].

\section{Früherkennungsuntersuchungen der Brust \\ $\nabla$}

Als alternative präventive Maßnahme im Vergleich zu prophylaktischen Brustoperationen können die intensivierten Brust-Früherkennungsuntersuchungen gelten. Das mittlere Erkrankungsalter für das familiäre Mammakarzinom ist auf das 45. Lebensjahr vorverlegt. Die allgemeinen Früherkennungsmaßnahmen sind im Risikokollektiv der Mutationsträgerinnen und der Risikofamilien ohne Mutationsnachweis nicht ausreichend, da das Mammografie-Screening erst nach dem 50. Lebensjahr beginnt. Zu diesem Zeitpunkt ist aber bereits ein Großteil der Frauen mit genetischer Belastung erkrankt. Aufgrund der Dichtigkeit des Drüsengewebes junger Frauen aus Risikofamilien führt die Mammografie als alleiniges Früherkennungsverfahren zu einer hohen Rate falsch negativer Befunde. Im Rahmen des Deutschen Konsortiums wurde deutschlandweit ein multimodales Früherkennungsprogramm mit engmaschigeren Screening-Intervallen und früherem Beginn angeboten $[3,16]$ ( $\bullet$ Tab. 3).

Früherkennungsuntersuchungen für das Ovarialkarzinom (halbjährliche transvaginale Sonografie, Bestimmung des Tumormarkers 
Screening for ovarian cancer (semi-annual transvaginal sonography, determination of the tumour marker CA 125) was not found to be efficient and is therefore not recommended [17].

\section{Prophylactic Surgery}

A number of risk-reducing surgical procedures are available for healthy $B R C A$-mutation carriers, including prophylactic bilateral mastectomy (PBM), prophylactic bilateral salpingo-oophorectomy (PBSO) and prophylactic contralateral mastectomy (PCM) for women who have already developed unilateral disease ( $\bullet$ Table 4). Patients need to be advised in detail of the risks and benefits of these surgical procedures through multidisciplinary, non-directive counselling prior to every surgical intervention. Prophylactic surgery must be based on an individual risk assessment by experts. The risks for the patient must be assessed individually in a "shared decision making" process together with the patient to arrive at a long-term solution which will be acceptable to the patient concerning the viability of prophylactic surgery.

\section{Prophylactic bilateral mastectomy}

PBM reduces the risk for a healthy $B R C A$-mutation carrier to develop breast cancer by around 95\% [18-20]. Complete mastectomy with removal of the mamilla-areola complex is currently considered to offer the safest option. Breast cancer developed more frequently after subcutaneous mastectomy than after complete mastectomy, although the long-term data are still provisional [19]. PBM should not be done prior to the age of 25 or prior to 5 years before the earliest age of disease onset in the risk family $[3,16]$. Preoperative counselling must include a discussion of the possibilities of primary and secondary reconstruction using heterologous or autologous tissue.

\section{Prophylactic contralateral mastectomy}

Most women who ask about prophylactic mastectomy have already developed unilateral breast cancer. They are primarily interested in avoiding another round of systemic treatment if they are considered to be at increased risk of developing a secondary carcinoma. An increased risk of developing secondary cancer has been reported for BRCA-mutation carriers [13]. BRCA1/2-negative women from risk families who have developed disease have no significantly increased risk of developing contralateral breast cancer compared to women with sporadic breast cancer [14]. Often the risk of recurrence or metastasis from the current cancer exceeds the risk to develop contralateral breast cancer. Counsel-
CA 125) zeigten keine Effizienz und werden daher nicht mehr empfohlen [17].

\section{Prophylaktische Operationen}

Für gesunde BRCA-Mutationsträgerinnen stehen als risikoreduzierende Operationsverfahren die prophylaktische beidseitige Mastektomie (PBM) und die prophylaktische beidseitige Salpingo-Oophorektomie (PBSO) bzw. die prophylaktische kontralaterale Mastektomie (PCM) für unilateral bereits erkrankte Frauen zur Verfügung ( Tab.4). Über Nutzen und Risiken dieser Verfahren sollte im Rahmen der multidisziplinären, nicht direktiven Beratung vor jedem Operationsverfahren ausführlich informiert werden. Eine prophylaktische Operation muss auf einer individuellen Risikoeinschätzung basieren, die von Experten durchgeführt werden muss. Zusammen mit der Ratsuchenden erfolgt dann im Prozess des „shared decision making“ eine individuelle Bewertung dieser Risiken, die schließlich zu einer für die Patientin langfristig tragbaren Entscheidung über die Inanspruchnahme prophylaktischer Operationen führt.

\section{Prophylaktische beidseitige Mastektomie}

Die PBM senkt das Risiko einer gesunden BRCA-Mutationsträgerin für eine Brustkrebserkrankung um über 95\% [18-20]. Die komplette Mastektomie mit Entfernung des Mamillen-Areola-Komplexes stellt derzeit die sicherste Maßnahme dar. Nach subkutaner Mastektomie sind häufiger Mammakarzinome aufgetreten als nach kompletter Mastektomie, wobei die Langzeitdaten noch präliminar sind [19]. Eine PBM sollte nicht vor dem 25. Lebensjahr bzw. 5 Jahre vor dem jüngsten Ersterkrankungsalter in der Familie durchgeführt werden $[3,16]$. Bei der präoperativen Beratung sollte obligat das Angebot der hetero- oder autologen primären und sekundären Rekonstruktion erörtert werden.

\section{Prophylaktische kontralaterale Mastektomie}

Die meisten Frauen, die die Frage nach einer prophylaktischen Mastektomie stellen, sind bereits einseitig an Brustkrebs erkrankt. Ihnen geht es primär darum, eine erneute Systembehandlung bei Vorliegen eines erhöhten Zweitkarzinomrisikos zu vermeiden. Für BRCA-Mutationsträgerinnen ist ein erhöhtes Zweitkarzinomrisiko beschrieben [13]. Für BRCA1/2-negative erkrankte Frauen aus Risikofamilien ergibt sich für das kontralaterale Mammakarzinom im Vergleich zu Frauen mit sporadischem Mammakarzinom kein signifikant erhöhtes Risiko [14]. Oft übersteigt das Risiko eines Rezidivs bzw. einer Metastasierung der aktuellen Erkrankung das Risiko für ein kontralaterales

Table 4 Recommendations for prophylactic surgery in healthy high-risk patients and high-risk patients with unilateral breast cancer with or without BRCA1/2 mutations [3].

\begin{tabular}{|c|c|c|c|}
\hline $\begin{array}{l}\text { BRCA muta- } \\
\text { tion status }\end{array}$ & $\begin{array}{l}\text { Past medical } \\
\text { history }\end{array}$ & Prophylactic mastectomy & Prophylactic salpingo-oophorectomy \\
\hline \multirow[t]{2}{*}{ Positive } & healthy & indicated on request - after the age of $25^{*}$ & indicated and expressly recommended - around the age of $40^{*}$ \\
\hline & $\begin{array}{l}\text { unilateral } \\
\text { breast cancer }\end{array}$ & $\begin{array}{l}\text { possible, particularly in younger persons, depending } \\
\text { on the affected gene, the age at primary diagnosis and } \\
\text { the prognosis }\end{array}$ & recommendation depends on prognosis \\
\hline \multirow[t]{2}{*}{ Negative } & $\begin{array}{l}\text { unilateral } \\
\text { breast cancer }\end{array}$ & $\begin{array}{l}\text { only to be considered in individual cases depending on } \\
\text { prognosis and individual risk (only limited data available) }\end{array}$ & $\begin{array}{l}\text { only to be considered in individual cases when there is a case } \\
\text { of ovarian cancer in the family }\end{array}$ \\
\hline & healthy & $\begin{array}{l}\text { only to be considered in individual cases where there is a } \\
\text { high statistical risk of disease (only limited data available) }\end{array}$ & no indication for prophylaxis and risk reduction \\
\hline
\end{tabular}

* or 5 years after the earliest age at onset of disease in a family member 
ling must include a discussion of the most recent studies and the patient's individual risk based on the patient's current age and mutation status and the prognosis for the primary disease.

\section{Prophylactic bilateral salpingo-oophorectomy}

Prophylactic bilateral salpingo-oophorectomy (PBSO) reduces the risk of developing ovarian cancer by $97 \%$ in healthy BRCAmutation carriers, although there is still a persistent $2 \%$ risk of developing primary extraovarian cancer [21]. In addition, PBSO reduces the risk of breast cancer by $50 \%$ [22] and the risk of developing contralateral secondary cancer by $30-50 \%$ [15, 23]. In addition to the cancer-specific decrease in mortality, Domchek et al. showed a decrease in mortality in women with breast cancer and a 75\% reduction in overall mortality after PBSO [20]. Laparoscopic PBSO is recommended for women after the age of 40 and for women who plan to have no more children, particularly in view of the lack of effective screening ( Table 3) [3]. Hormone replacement therapy until the age of natural menopause (approx. 50 years of age) does not increase the risk of breast cancer and is recommended.

In summary it can be stated that, with the exception of the benefits reported for PBSO for healthy BRCA-mutation carriers and for $B R C A$-mutation carriers who have already developed breast cancer, there is still no reliable data available on the efficacy of prophylactic surgery for BRCA-mutation carriers with disease or for $B R C A 1 / 2$-negative healthy high-risk persons or BRCA1/2-negative women who have developed disease. The decision for prophylactic surgery must therefore only be taken with great circumspection and after extensive counselling as part of a shared decisionmaking process.

\section{Self-help \\ $\nabla$}

Non-directive medical counselling on the pros and cons of preventive surgery must include, in addition to a discussion of the risk of developing disease and risk reduction, a consideration of the woman's current personal situation and her ideas concerning the future. A direct discussion with affected women about their experiences can convey what it means to live with the decision they have taken. The German BRCA Network (BRCA Netzwerk e.V.), set up in 2008 by women with disease and healthy women from risk families, offers support from the perspective of affected women. The informative homepage of the network, which was set up with the support of the German Cancer Aid, offers hints and information on a range of topics with a focus on self-help (http://www.brca-netzwerk.de). Affected women are offered support to make an informed decision with regard to potential preventive options. That is also the goal of local discussion groups which have been set up all over Germany. More and more discussion groups are being set up. The heads of the BRCA network are also integrated in all executive committees of the German Consortium to ensure that the voices of affected women are heard and their concerns are integrated as far as possible in their care.

\section{Conclusion}

$\nabla$

- With the exception of PBSO for BRCA-mutation carriers, currently no reliable data are available on the effectiveness of prophylactic surgery. The decision for prophylactic surgery should
Mammakarzinom deutlich. In die Beratung sollten die aktuelle Studienlage und die individuelle Risikoeinschätzung anhand des aktuellen Lebensalters, des Mutationsstatus und der Prognose der Ersterkrankung unbedingt eingehen.

\section{Prophylaktische beidseitige Salpingo-Oophorektomie}

Bei gesunden BRCA-Mutationsträgerinnen reduziert die prophylaktische beidseitige Salpingo-Oophorektomie (PBSO) das Ovarialkarzinomrisiko um $97 \%$ bei Weiterbestehen des $2 \%$ igen Risikos für ein primär extraovarielles Ovarialkarzinom [21]. Zusätzlich wird durch die PBSO das Brustkrebsrisiko um 50\% [22] und das Risiko für ein kontralaterales Zweitkarzinom um 30-50\% reduziert [15,23]. Neben der krebsspezifischen Mortalitätssenkung konnten Domchek et al. für die PBSO eine Mortalitätssenkung bei bereits an Brustkrebs erkrankten Frauen und eine 75\%ige Reduktion der Gesamtmortalität zeigen [20]. Empfohlen wird die PBSO als laparoskopischer Eingriff ab dem 40. Lebensjahr und nach abgeschlossener Familienplanung insbesondere angesichts fehlender effektiver Früherkennungsmaßnahmen ( Tab. 3) [3]. Eine hormonelle Substitution bis zum Eintritt in die natürlichen Wechseljahre (ca. 50. Lebensjahr) steigert das Brustkrebsrisiko nicht und wird empfohlen.

Zusammenfassend kann festgehalten werden, dass bis auf die PBSO bei gesunden und bereits an Mammakarzinom erkrankten BRCA-Mutationsträgerinnen bisher keine zuverlässigen Daten zur Effektivität der prophylaktischen Operationen vorliegen, weder für erkrankte Mutationsträgerinnen noch für BRCA1/2-negativ getestete gesunde oder bereits erkrankte Hochrisikopersonen. Die Indikation zu prophylaktischen Operationen kann daher nur mit größter Vorsicht und nur nach ausführlicher Beratung im Rahmen eines informierten Entscheidungsprozesses gestellt werden.

\section{Selbsthilfe \\ $\nabla$}

Die nicht direktive ärztliche Beratung zu Pro und Contra der Inanspruchnahme präventiver Maßnahmen beinhaltet neben der Darstellung von Erkrankungsrisiken und Risikoreduktion die Berücksichtigung der persönlichen Lebenssituation der Ratsuchenden und deren eigene Vorstellungen. Der direkte Austausch mit Betroffenen kann vermitteln, was es bedeutet, mit den getroffenen Entscheidungen zu leben. Das BRCA-Netzwerk e.V., das 2008 von gesunden und erkrankten Frauen aus Risikofamilien gegründet wurde, bietet Unterstützung aus der Perspektive von Betroffenen. Auf der informativen Homepage des Netzwerks, die mit Unterstützung der Deutschen Krebshilfe e.V. aufgebaut wurde, werden Tipps rund um die im Fokus der Selbsthilfe stehenden Themen gegeben (http://www.brca-netzwerk.de). Betroffene sollen insbesondere bei der informierten Entscheidung im Hinblick auf mögliche präventive Optionen unterstützt werden. Dies ist auch Ziel der lokalen Gesprächskreise, die sich in ganz Deutschland gegründet haben und gründen. Die Leiterinnen des BRCA-Netzwerks sind in alle Leitungsgremien des Deutschen Konsortiums integriert, um den Betroffenen größtmögliches Gehör zu verschaffen und deren Belange bestmöglich in die Betreuung zu integrieren.

\section{Fazit}

$\nabla$

- Außer für die PBSO bei BRCA-Mutationsträgerinnen liegen bisher keine zuverlässigen Daten zur Effektivität der prophylaktischen Operationen vor, daher kann die Indikation zu prophylaktischen Operationen nur mit größter Vorsicht und nur nach ausführlicher 
therefore only be taken very circumspectly and after extensive counselling in a shared decision-making process.

- The risk of developing secondary contralateral breast cancer is widely distributed and depends on mutation status and age at primary diagnosis. This risk should always be communicated to the patient and discussed together with the prognosis for the primary disease.

- Non-directive counselling with a discussion of (competing) risks (e.g. from the primary disease) and of the options for immediate reconstruction must be done prior to every prophylactic mastectomy. Prophylactic bilateral salpingo-oophorectomy is indicated in BRCA-mutation carriers above the age of 40 or 5 years prior to the youngest age at onset of ovarian cancer in the patient's family.

- The BRCA network provides support by other affected women for the decision-making processes and to help evaluate the pros and cons of a genetic diagnosis and of prophylactic surgery.

\section{Conflict of Interest \\ $\nabla$}

None.

\section{References}

1 Robert Koch-Institut, Zentrum für Krebsregisterdaten. http://www. krebsdaten.de/Krebs/DE/Content/Krebsarten/Brustkrebs/brustkrebs_ node.html; Stand: 23.08.2012

2 http://www.krebsgesellschaft.de/download/fb_erbliche_belastung 110106.xls; Stand: 23.08.2012

3 Meindl A, Ditsch N, Kast K et al. Hereditary breast and ovarian cancernew genes, new treatments, new concepts. Dtsch Arztebl Int 2011; 108: 323-330, DOI: 10.3238/arztebl.2011.0323

4 Meindl A, Hellebrand H, Wiek C et al. Germline mutations in breast and ovarian cancer pedigrees establish RAD 51C as a human cancer susceptibility gene. Nat Genet 2010; 42: 410-414

5 Soegaard M, Kjær SK, Cox M et al. BRCA1 and BRCA2 mutation prevalence and clinical characteristics of a population-based series of ovarian cancer cases from Denmark. Clin Cancer Res 2008; 14: 3761-3767

6 Lakhani SR, Manek S, Penault-Llorca F et al. Pathology of ovarian cancers in BRCA1 and BRCA2 carriers. Clin Cancer Res 2004; 10: 2473 2481

7 Chetrit A, Hirsh-Yechezkel G, Ben-David Y et al. Effect of BRCA1/2 mutations on long-term survival of patients with invasive ovarian cancer: the national Israeli study of ovarian cancer. J Clin Oncol 2008; 26: 20 25

8 Cass I, Baldwin RL, Varkey T et al. Improved survival in women with BRCA associated ovarian carcinoma. Cancer 2003; 97: 2187-2195

9 Bolton KL, Chevenvix-Trench G, Goh C et al. Association between BRCA1 and BRCA2 mutations and survival in women with invasive enpithelial ovarian cancer. JAMA 2012; 307: 382-390

10 Foulkes WD, Stefansson IM, Chappuis PO et al. Germline BRCA1 mutations and a basal epithelial phenotype in breast cancer. J Natl Cancer Inst 2003; 95: 1482-1485

11 Lakhani SR, Reis-Filho JS, Fulford L et al. Prediction of BRCA1 status in patients with breast cancer using estrogen receptor and basal phenotype. Clin Cancer Res 2005; 11: 5175-5180

12 Robson ME, Chappuis PO, Satagopan J et al. A combined analysis of outcome following breast cancer: differences in survival based on BRCA1/ BRCA2 mutation status and administration of adjuvant treatment. Breast Cancer Res 2004; 6: R8-R17
Beratung im Rahmen eines informierten Entscheidungsprozesses gestellt werden.

- Die Risiken für ein 2., kontralaterales Mammakarzinom streuen sehr; sie hängen vom Mutationsstatus sowie dem Alter bei Ersterkrankung ab und sollten immer unter Berücksichtigung der Prognose der Ersterkrankung kommuniziert werden.

- Vor jeder prophylaktischen Mastektomie muss eine nicht direktive Beratung mit Besprechung der (konkurrierenden) Risiken (z. B. aufgrund der Ersterkrankung) und den Optionen zur Sofortrekonstruktion erfolgen.

- Die prophylaktische beidseitige Salpingo-Oophorektomie ist bei BRCA-Mutationsträgerinnen ab dem 40. Lebensjahr bzw. 5 Jahre vor dem jüngsten Ersterkrankungsalter an Eierstockkrebs in der Familie indiziert.

- Das BRCA-Netzwerk kann vonseiten der Betroffenen in den Entscheidungsfindungsprozessen von Für und Wider Gendiagnostik bis prophylaktische Operationen unterstützend wirken.

\section{Interessenkonflikt}

\section{$\nabla$}

Nein.

13 Graeser MK, Engel C, Rhiem $K$ et al. Contralateral breast cancer risk in BRCA1 and BRCA2 mutation carriers. J Clin Oncol 2009; 27: 1-6

14 Rhiem $K$, Engel C, Graeser $M$ et al. The risk of contralateral breast cancer in patients from BRCA1/2 negative high risk families as compared to patients from BRCA1- or BRCA2 positive families: a retrospective cohort study. Breast Cancer Res [in press]

15 Metcalfe K, Lynch HT, Ghadirian P. Contralateral breast cancer in BRCA1 and BRCA2 mutation carriers. J Clin Oncol 2004; 22: 2328-2335

16 Albert $U$. Stufe-3-Leitlinie Früherkennung, Diagnostik und Therapie des Mammakarzinoms. München: Zckschwerdt; 2008

17 Bosse K, Rhiem K, Wappenschmidt B et al. Screening for ovarian cancer by trans-vaginal ultrasound and serum CA125 measurement in women with familial pre-disposition; a prospective cohort study. Gynecol Oncol 2006; 1033: 1077-1082

18 Meijers-Heijboer H, van Geel B, van Putten WL et al. Breast cancer after prophylactic bilateral mastectomy in women with BRCA1 and BRCA2 mutation. N Engl J Med 2001; 345: 159-164

19 Rebbeck TR, Friebel T, Lynch HT; The PROSE Study Group. Bilateral prophylactic mastectomy reduces breast cancer risk in BRCA1 and BRCA2 mutation carriers. J Clin Oncol 2004; 22: 1055-1062

20 Domchek SM, Friebel TM, Neuhausen SL et al. Mortality after bilateral salpingo-oophorectomy in BRCA1 and BRCA2 mutation carriers: a prospective cohort study. Lancet 2006; 7: 223-229

21 KauffND, Satagopan JM, Robson ME et al. Risk reducing salpingo-oophorectomy in women with BRCA1 and BRCA2 mutation. N Engl J Med 2002; 346: 1609-1615

22 Kauff ND, Domchek SM, Friebel TM et al. Risk reducing salpino-oophorectomy for the prevention of BRCA1- and BRCA2-associated breast and gynecologic cancer: a multicenter, prospective Study. J Clin Oncol 2008; 26: 1331-1337

23 Pierce LJ, Levin AM, Rebbeck TR et al. Ten-year multi-institutional results of breast-conserving surgery and radiotherapy in BRCA1/2-associated stage I/II breast cancer. J Clin Oncol (United States) 2006; 24: 2437-2443

Deutschsprachige Zusatzinformationen online abrufbar unter: www.thieme-connect.de/ejournals/toc/gebfra. 